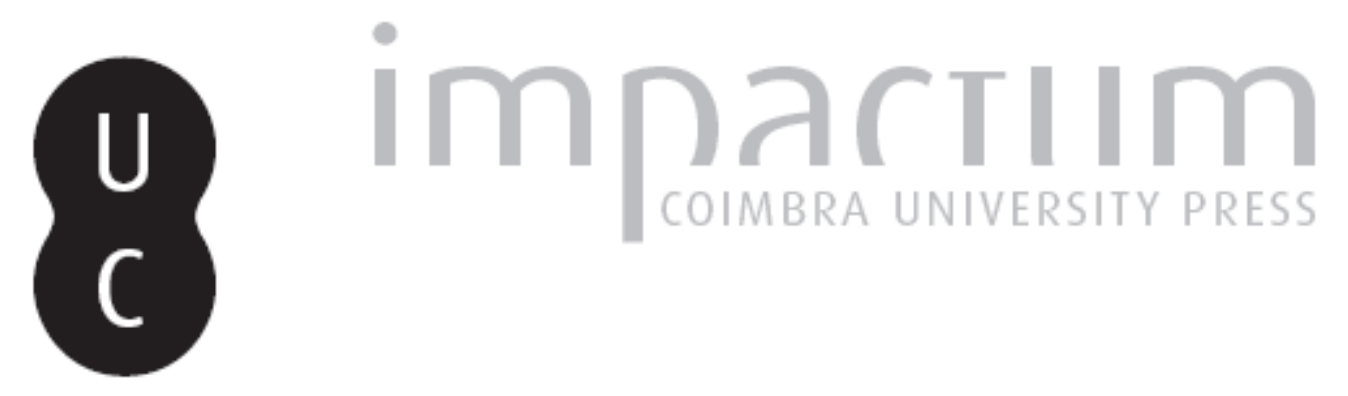

\title{
Plato's Republics
}

\section{Autor(es): $\quad$ Tarrant, Harold}

Publicado por: Imprensa da Universidade de Coimbra

URL persistente:

URl:http://hdl.handle.net/10316.2/42171

DOI:

DOI:https://doi.org/10.14195/2183-4105_12_5

Accessed : $\quad$ 26-Apr-2023 07:32:46

A navegação consulta e descarregamento dos títulos inseridos nas Bibliotecas Digitais UC Digitalis, UC Pombalina e UC Impactum, pressupõem a aceitação plena e sem reservas dos Termos e Condições de Uso destas Bibliotecas Digitais, disponíveis em https://digitalis.uc.pt/pt-pt/termos.

Conforme exposto nos referidos Termos e Condições de Uso, o descarregamento de títulos de acesso restrito requer uma licença válida de autorização devendo o utilizador aceder ao(s) documento(s) a partir de um endereço de IP da instituição detentora da supramencionada licença.

Ao utilizador é apenas permitido o descarregamento para uso pessoal, pelo que o emprego do(s) título(s) descarregado(s) para outro fim, designadamente comercial, carece de autorização do respetivo autor ou editor da obra.

Na medida em que todas as obras da UC Digitalis se encontram protegidas pelo Código do Direito de Autor e Direitos Conexos e demais legislação aplicável, toda a cópia, parcial ou total, deste documento, nos casos em que é legalmente admitida, deverá conter ou fazer-se acompanhar por este aviso. 
O

Established 1989

$\bigcirc$

$\vdash$

$<$

$\dashv$

ㅇ

-
$Z$
0
-
1
$Z$
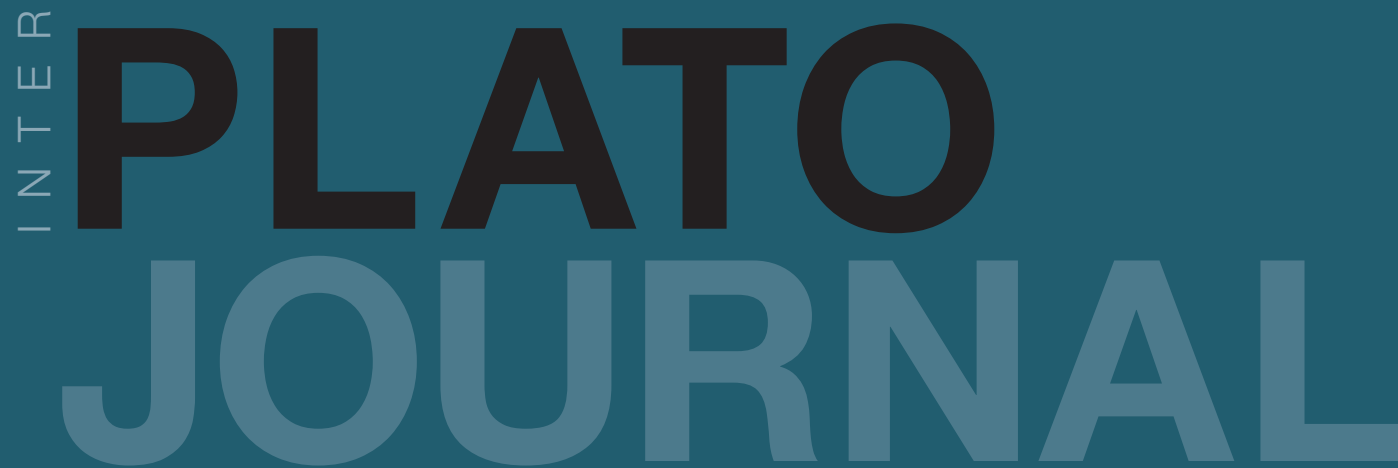

Société Platonicienne Internationale

Associazione Internazionale dei Platonisti

Sociedad Internacional de Platonistas

Internationale

Platon-Gesellschaft 


\title{
PLATO'S REPUBLICS
}

\author{
Harold TARRANT
}

\begin{abstract}
Various ancient sources refer to the Platonic work that we know as Republic in the plural. Aristotle seems to have made it possible to refer to politeiai as 'constitutions', actual or written, and therefore some of our texts are best explained as references to Plato's two written constitutions, Republic and Laws. One neglected reference that may perhaps be explained in this way occurs in the anonymous Antiatticista. A large number of references from the Alexandrian school of Platonism in late antiquity cannot be explained in that way, and should be understood with reference to the prevalent interpretation of the Republic, which gives equal weight to the internal (psychic) and external (civic) constitutions. The trickiest question is what it means in the titles of three commentaries dating from the early imperial era.
\end{abstract}

\section{Introduction}

The way that Plato's Republic was cited in antiquity has important consequences for our understanding of the history of its reception. In particular it has a bearing on the history of commentary on the work, on the interrelation between title and exegesis in late antiquity, and possibly even on the manuscript tradition since the important Parisinus Graecus 1807 (A) and dependent manuscripts placed 'Republics or On Justice' at its commencement. ${ }^{1}$ As we shall see, ancient titles were often not so much the definitive product of authorial intention as a convenient description for others referring to the work. The early absence of anything equivalent to the capital letter made it natural to think of many titles as being flexible, and it is well known that works like the Phaedo (On Soul) and Critias (Atlantikos) were regularly known by alternative titles in antiquity. There is a special problem that it was impossible to distinguish between Plato's Republic and his 'constitution', usually the constitution outlined within the Republic.

Various ancient sources refer to the Platonic work that we know as Republic in the plural: not Politeia but Politeiai. There has been a certain amount of discussion as to why this should be so. ${ }^{2}$ The tradition of a plural title involves both philosophers and grammarians, two groups who ought to have interacted in

\footnotetext{
${ }^{1}$ Details in Slings (2003); note that Slings misleadingly reports the Antiatticist as preserving the plural title, without indicating that this was written only in one of a great many citations in the work.

${ }^{2}$ Westerink (1981); Dörrie \& Baltes (1993), 203-4; Hatzimichali (2012) 72-73.
}

PLATO, The electronic Journal of the International Plato Society, 12, 2012.

http://gramata.univ-paris1.fr/Plato/article118.html,

(c) All rights of reproduction of any form reserved. 
antiquity but might have done so only intermittently. The primary issue is whether the plural Politeiai was even used as a title before the fifth century AD. I begin with the evidence of a grammarian whose work has not been sufficiently pondered in this regard, and after a few extra lines on the grammatical tradition I move to the citations of the Republic by the philosophers, from Aristotle to late antiquity. Special attention must be paid to a number of citations of exegetical works on the Politeiai that appear to date from early imperial times.

\section{The Antiatticist}

It has recently come to my attention that there is a citation that uses the plural title in the anonymous Antiatticista, published in Bekker's 1814 Anecdota Graeca. ${ }^{3}$ This text is a collection of linguistic forms (words, inflections, and words in certain meanings) that failed to meet the approval of atticizing grammarians bent on removing Koine influences. In this text, arranged roughly in alphabetic order, the author notes where such words have been used in Attic and other respected Greek literature. At p. 110.19 Bekker we read:

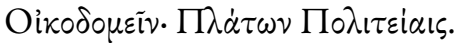

The initial uncertainty as to his intention is whether he wishes to refer to the philosopher or the comic playwright, for he generally refers to Plato's Republic (i) with a singular title, and (ii) by book number, using an unfamiliar division into six books. However at six points he uses the expected words $\Pi \lambda \dot{\alpha} \tau \omega \nu$ По $\lambda\llcorner\tau \varepsilon i \alpha$, without mention of a book (82.11, 94.19, 94.30, 111.16, 116.9 and 25). Though it is conceivable that the plural form is some strange title from Plato Comicus, since other strange titles in the plural are known (normally indicating the identity

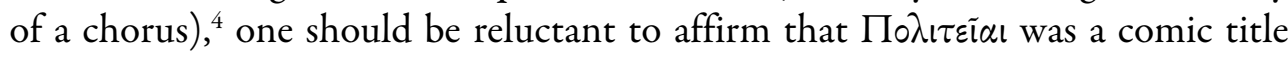
when examples of the citation of Republic in this plural form seem to exist. There is actually one example in the Antiatticista of the Republic being named as

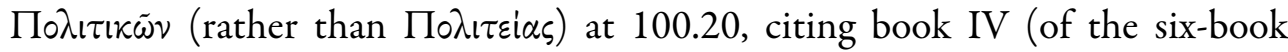
version) and clearly meant to refer to $462 \mathrm{~b} 8$ (in our book V).

\footnotetext{
3 Bekker (1814). [Text of Antiatticist $=1.75-116$ ] The surviving work is abridged (Lee forthcoming), with resultant problems in identifying quite what the Antiatticist himself was trying to say. The best internal indication of a date occurs at 79.31-32 reads as follows: 'A $A \varepsilon \tau \varepsilon i \nu$

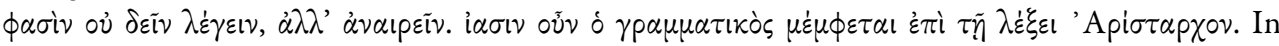
Tarrant (2012), 72 with n.55, I argue that for $i \alpha \sigma \nu$ oṽv we should read 'I $\dot{\alpha} \sigma \omega \nu$ (perhaps with oṽv), referring to Iason the grammarian mentioned by the Etymologicum Magnum (184.27), while Aristarchus is the Samothracian (c.220-143BC), successor to Aristophanes of Byzantium. A date any time up to the second century $\mathrm{AD}$ is theoretically possible.

4 Tarrant (2012), 55 and 63.
}

PLATO, The electronic Journal of the International Plato Society, 12, 2012.

http://gramata.univ-paris1.fr/Plato/article118.html,

(c) All rights of reproduction of any form reserved. 
If we take the reference to Politeiai to refer to Plato's Republic we encounter the difficulty that the author will normally select the right voice in which to cite a verb, while both the references in Plato's Republic (372a6-7, 419a5-6) use this verb in the middle voice rather than the active. The active can be found in the Charmides (161e6, 165d5, both present infinitive), Laws (643b8, 858b7, present participles), and Gorgias (514b6, perfect indicative), though of these works only Gorgias is ever cited by the Antiatticista. In order to resolve the difficulties one might be led to propose various emendations. For instance, the text might

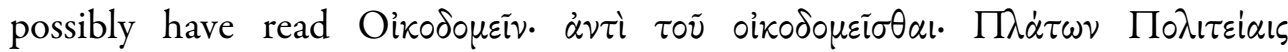
(implying that the middle is used where the active would be normal), ${ }^{5}$ since the trouble with the active is that it is probably the more regular form in classical times, so that atticizing grammarians can hardly have frowned on it, at least when used in the simple sense of 'build'. It is forms rare in Attic that are likely to be cited in such a work.

One actually does find related terminology among the Atticist lexicographers, for Phrynichus rejects the Koine noun oikodoun in favour of the Attic oikodó $\mu \eta \mu \alpha$ (Eclogues 395). Furthermore, as we shall see below, two late texts are witness to discussion by unknown grammarians of the active and middle voices of the verb

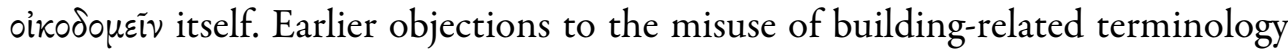
may have prompted the Antiatticista's citation of this series of three connected terms-not only the verb in the active, but also (110.20-21) oikodouia (cited only for Thucydides VII, but found at Rep. 394a5) and oikodóunols (again only cited for Thucydides VII, ${ }^{6}$ but found at Rep. 401a3). These lines are very compressed, suggesting that something may have been lost in the abridgement of the original material. That in turn may possibly explain a lack of precision. One should therefore ask whether the grammarian is predisposed to a lack of precision at the point. With that end in view we shall examine the distribution of those cases where a book is not specified for Republic or for either Herodotus or Thucydides. We shall also consider when the wrong book is cited for Herodotus or Thucydides, though we cannot do this systematically for the Republic because the boundaries of most books are unknown, and it cannot be assumed that none of the content has been rearranged, as I have argued (Tarrant 2012).

The normal method of citing the Republic in this work is to follow the word that is subject to comment with 'Plato' [nom.] Politeia [gen.] book-number [dat.]; that order may follow the specification of a required sense or receive some further addition. A total of 26 cases follow this pattern. A further 7 cases have reversed

\footnotetext{
5 One might also consider the possibility that some alternative word for 'build' had been cited before dropping out, for instance $\kappa \alpha \tau \alpha \sigma \kappa \varepsilon \nu \dot{\alpha} \zeta \varepsilon เ \nu$ (for building a city at $557 \mathrm{~d} 3$ ), but the omission of an etymologically unrelated form would be harder to explain, as would the presence of its entry at this point of the largely alphabetic lexicon.

${ }^{6}$ This should have been the third book, III.2.2 or 21.1; the previous form was found at VII.6.4.
} 
the genitive of the title and the book-number. But 7 cases (including the one under consideration) omit the book number, and place the title in the dative. In these seven, six cases fail to capture the correct form of the word in our texts, although this is usually the author's practice, with the result that a noun might be cited in any case, or a verb in any voice or tense. It is natural to infer that the bulk of the author's material comes from notes taken while reading the texts, resulting in greater precision, but that a few entries are based on memory, no attempt being made to check the original. The author wishes to add something further at this point, and he may either omit or guess at the correct book-number. Omissions are found as in table 1 :

$\begin{array}{lcccccc}\text { Bekker page } & \text { Republic } & \text { Thucydides } & \text { Herodotus } & \text { Total } & \text { Refs. } & \text { Percentage } \\ 77-81 & 0 & 0 & 0 & 0 & 20 & 0 \\ 82-83 & 1 & 0 & 1 & 2 & 7 & 28.57 \\ 84-91 & 0 & 0 & 0 & 0 & 15 & 0 \\ 92-95 & 2 & 3 & 0 & 5 & 19 & 26.32 \\ 96-106 & 0 & 0 & 1 & 1 & 37 & 2.7 \\ 107-111 & 2 & 1 & 0 & 3 & 23 & 13.04 \\ 112-116 & 2 & 1 & 2 & 6 & 12 & 41.67\end{array}$

Table 1: Citations without book-number

Clearly the omissions of book numbers are concentrated at certain points, including 82-83, 92-95, and the last few pages. They are less striking when part of a list of authorities, as in the case of Herodotus at 83.31, but the impression of inaccurate memory-work may be enhanced, as when the lexical entry is misspelt, as at 100.23 (if the text is correctly preserved) with i $\sigma$ Xó $\phi \omega v o v$ for Herodotus' ioxvó $\phi \omega \nu$ v (4.155). ${ }^{7}$ The overall problem increases towards the end of the work, which seems unnaturally compressed. We do not meet the entries for mu until p. 107, thirty pages through Bekker's text, and nu to omega are disposed of in pp. 109-116. Entries seem too few as well as too brief. References that lack the citation of a book number for these works are particularly common at pp. 113-16. The compression may have been the work of an epitomator, which Lee (2013) has quite reasonably argued for, though one would have to postulate a process that is, in general, much more ruthless at the end than at the beginning. ${ }^{8}$ An alternative might be that the work was never properly finished. From p. 110 none of the remaining seven references to Plato's Republic are entirely unproblematic, and an example would be the citation of the simple verb instead of the compound $\dot{\varepsilon} \pi \iota p \omega \mu \alpha \tau i \zeta \varepsilon\llcorner\nu$ (Rep. 601a5). There is no guarantee that the author had found the

\footnotetext{
7 Besides the omission of the nu, note the Antiatticista's default accusative for a form that had appeared in the nominative in Herodotus.

8 Rather than a diligent epitomator carefully excising the same kind of unwanted material throughout, it seems that this would be a person who has increasing doubts about the overall use of the work in question as he approaches the end of the task.
}

PLATO, The electronic Journal of the International Plato Society, 12, 2012.

http://gramata.univ-paris1.fr/Plato/article118.html,

(c) All rights of reproduction of any form reserved. 
compound in his text, ${ }^{9}$ but, seeing that the book number is not given, faulty memory may well be to blame. However, of six references to other Platonic works at pp. 110-116, only p. 116.29 , which I relate to Gorgias $485 \mathrm{e},{ }^{10}$ should give any concern.

If we conclude that the failure to cite a book number is an indication that the original author is working from memory rather from notes taken while reading, then we are not expecting that the reference to Politeiai rather than to a single Politeia is aiming to convey precise information. Most likely it is just an observation that, in spite of the grammarians' tendency to condemn certain oikterms in certain senses, many of them were entirely legitimate. If we had known that Plato Comicus had written a play of this title then we should see it as a reference to him, but in the present circumstances it seems more probable that we are dealing with some kind of attempt to derive the forms required from Plato the philosopher, an author who does indeed use many of them. However, the author is unlikely to have temporarily forgotten the usual title of the Republic that he employs so often elsewhere, ${ }^{11}$ and we should consider seriously the possibility that he is trying to refer either to more than one version of the Republic (Politeiai) ${ }^{12}$ or more likely to those Platonic works that deal with constitutions (politeiai). Not only would this latter solution help to explain the active voice of the verb (cf. Laws 643b8, 858b7), but as we shall see there may have been a precedent for the use of the plural in this sense in Aristotle.

I believe that the correct solution to the problem in the Antiatticista actually involves both Republic and Laws. If the Atticists were going to condemn a sense

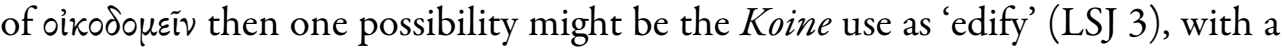
personal object, but Plato could not be said to offer any comparable example. More probable here is that an exception had been made to the use of the active in what is properly the middle sense, of having a house built rather than performing all the work oneself. It could be argued that this is the sense in which Plato intends both middle-voice forms in the Republic, particularly at 419a5-6 but possibly also at 372a6-7. However, the active forms in Laws both relate to the actual builder, ${ }^{13}$ one learning to be a builder and needing to play at building

\footnotetext{
9 Tarrant (2012), 60 n.24.

10 Tarrant (2012), 57.

11 Here again I mention the single exception of the work's being cited as 'Politics' at 100.20.

12 This possibility arises only if the six-book arrangement differed significantly in content from the ten-book work, as Tarrant (2012) has argued; but the author shows no other signs of awareness that a fuller version exists. This should be balanced against the fact that he shows no signs of having studied Laws.

13 Both examples of the active in Charmides (161e, 165d) also involve the actual act of building, though this is not so clear at Gorgias 514b, where one may only assume that the 1st person plural subject will include the actual builder.
}

PLATO, The electronic Journal of the International Plato Society, 12, 2012.

http://gramata.univ-paris1.fr/Plato/article118.html,

(c) All rights of reproduction of any form reserved. 
(642b-c), and, in an elaborate analogy (858b), one who is actually 'building' a lawcode out of assembled materials. So Plato's two constitutional works are actually a model of how the two voices should be employed. Clearly the surviving version of the Antiatticista does not specify this, but it may well be that the epitomator has omitted material that would have cited Plato's Politeiai as a possible source for the correct use of the voices of this verb, material ultimately derived not from the Antiatticista's personal reading but from one of the grammarians whose work he draws on and qualifies; for grammarians had at some time certainly discussed the voices of oikodoukiv in relation to both Homer and Demosthenes. ${ }^{14}$

This solution, like almost any solution that will appeal to the loss of information thanks to the activities of an epitomator, can be regarded as provisional only. The Antiatticista is not an easy author to fathom. We must now look at the remaining evidence.

\section{Boethus the Platonic Lexicographer}

Another linguistic work cites Plato in a similar way centuries later, the Etymologicum Magnum. Elsewhere it cites the Republic quite normally in the singular (e.g. $31.20,199.7,769.35,777.14$ ), but at 789.45 we read of the word $\phi a \tilde{\lambda}$ os:

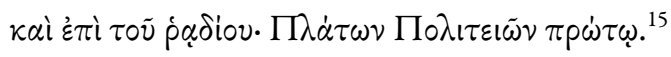

This late citation would be irrelevant to our present purpose, but for the fact that the entry has a complicated history, and this has led to its being regarded as fragment 5 of Boethus the Platonic lexicographer, who may not be far separated in date from the Antiatticista. Owing to the complications, there is no guarantee that either the fragment itself, assigned to Boethus because of structural similarities with fragments 1 and $4,{ }^{16}$ or more particularly the plural form of the Platonic title, goes back to early imperial times. The Platonic title may have resulted from a very late 'correction'. ${ }^{17}$

14 Thomas Magister, p. 214.13-16 Ritschl (s.v. $\kappa \alpha \tau \alpha \sigma \kappa \varepsilon v \dot{\alpha} \zeta \omega)$ ), shows that grammarians had

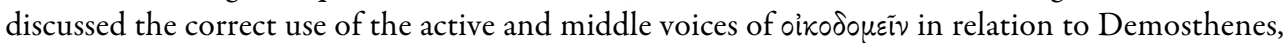
while a scholion on Iliad 24.281 a shows that this example had already been used to illustrate the meaning of the Homeric middle at a time when Homeric scholarship had flourished.

15 For 'first' it is clear from the citation of Rep 423c5-6 that 'fourth' should be read if the usual ten-book arrangement is being cited; for details see Dyck (1985), 79-80, 83-84.

${ }^{16}$ Dyck (1985), 83-84.

${ }^{17}$ For the special problems of dating any individual pieces of text within lexical works see Bonelli (2008), 25: 'aucun argument de la forme 'Notre texte du Lexique fait référence à X: donc Timée a écrit après X' n'est solide, car il est toujours possible que la référence à X soit un ajout tardif.' One must expect common material with no acknowledgment of borrowing, and allow that alien

PLATO, The electronic Journal of the International Plato Society, 12, 2012.

http://gramata.univ-paris1.fr/Plato/article118.html,

(c) All rights of reproduction of any form reserved. 


\section{Aristotle}

Aristotle has no difficulty in using the singular for the title of the work we know as 'Republic', and it is the only title used when discussing that work in Politics II.16 (1261a6, 9; 1264b28), but at IV.7 we read that 'people use only the four [constitutions] just like Plato in the politeiai' (1293b42-94a1). I avoid a titleindicating capital letter, since Aristotle did not have it available, and for the same reasons I omit the brackets in which modern editors enclose 'just like Plato'. ${ }^{18}$ I assume that Aristotle is referring to the two written 'constitutions' (1260b29-30) of Plato that he had dealt with previously at II.1-6, both of which had failed to take note of the 'polity' (in Aristotle's special sense), allegedly contenting themselves with just four forms, monarchy, oligarchy, democracy, and aristocracy. This is hardly an accurate account of Republic VIII-IX where five constitutions are enumerated, nor of Statesman 291d-292a (three or five, with six at 302d-e); it is less a distortion of Laws IV 709e-713a, ${ }^{19}$ where Plato comes frustratingly close to using the word politeia in its Aristotelian sense. While Dörrie-Baltes (III, 204 n.1) supports Westerink's (1981) proposal to interpret this reference as a general one to Plato's political works, it is perhaps unnecessary to be certain of what Aristotle wrote here; we need to suppose only that the text that was transmitted could be taken to refer to Plato's two works that discussed his type of constitution.

material may have been added. A vitally important modern case of such additions is the TLG text of Timaeus' Platonic Lexicon that uses the 'text' of Baiter et al. (1839), which has been 'restored' to proper alphabetic order and infused with much alien material from lexica and Byzantine encyclopaedias (Bonelli, 2008, 9). Baiter and his colleagues had in fact distinguished other material by the use of a different font. Hence the entry in the Antiatticista that we have dealt with will also appear (falsely) as a passage of Timaeus Sophista! In this appendix (970-1010) appear 9 further glosses of a linguistic character that appear to refer to 'Republics'. Their narrow range suggests a single source, which is ultimately the Eclogues attributed to the very late Thomas Magister, the standard edition of which is Ritschl (1832). Thomas continues the Atticist tradition, drawing on earlier authors extensively (Lee 2013). The problem is that one cannot date the cluster of references to Politeiai. None of this cluster cite books three to ten. Some of those that cite a book relate to specific passages in Republic I or II, though 995 b11 does not obviously do so, 986a12 seems is citing via Aristides' speech Against Plato on Rhetoric 11.27, and 986a15 actually relates to Theaetetus $143 \mathrm{a} 4$. At $975 \mathrm{~b} 7$ one reads 'in one of his Republics' as if the intention was to say 'either Republic or Laws', and the quotation is imprecise enough to leave doubts as to which work is cited.

18 Westerink (1981) 112; I ignored here the possibility that there has been a gloss at this point, which affects my argument only if the gloss is late enough to have been unknown to the Antiatticista.

19 The most exact parallel to Aristotle's group of four is not at 710e3-6, which omits aristocracy and includes tyranny, but at $712 \mathrm{c} 2-5$ where Cleinias is speaking, and explains why he omits tyranny.

PLATO, The electronic Journal of the International Plato Society, 12, 2012.

http://gramata.univ-paris1.fr/Plato/article118.html,

(c) All rights of reproduction of any form reserved. 


\section{Commentary-titles}

Early in the history of commentary on Plato we find two titles that couple the term most often used to denote a commentary, hypomnêma or hypomnêmata, with the name of Plato and the plural Politeiai. They have naturally been taken to indicate some kind of commentary on the Republic. However, though we are familiar with many interpretative works that relate to the Republic, we do not actually know of any tradition of commenting on the Republic that involved a succession of lemmata taken in order in the same way as most surviving commentaries on Plato did. Unlike other Proclan commentaries, the Proclan 'Commentary' on the Republic consists of a series of hermeneutic essays. We do not have papyrus fragments that can with confidence be said to come from a regular commentary on the work. We are aware of several works on aspects of the Republic ${ }^{20}$ especially its mathematical aspects, whose authors included Clearchus, Dercyllides, Dionysius of Halicarnassus, possibly Theon of Smyrna, ${ }^{21}$ and possibly Taurus of Sidon (or Beirut). ${ }^{22}$ Again, of the two of Plutarch's Quaestiones Platonicae that concern the Republic, the third (1001c-1002e) is concerned with mathematics (namely the Divided Line), while the ninth is not. Thanks to Proclus (in Remp. II.96.10-15 = Dörrie-Baltes III 76.4), and ultimately probably to Porphyry, we have quite a list of pre-Porphyrian interpreters who tackled the Myth of Er in particular, but most probably did so in works on the nature of the soul. Hence, what we lack is a reference to regular commentaries, ${ }^{23}$ and one of the reasons for this was no doubt the likelihood that such a commentary would have been a monumental undertaking, longer than the Platonic original. It is appropriate therefore that we take a fresh look at the plural titles, asking whether they could not have been exegetical works that set out to discuss Plato's constitutions, i.e. the arrangements for governance and social organisation, in both Republic and Laws.

\footnotetext{
${ }^{20}$ See Dörrie-Baltes (1993) 80.1, 3, 5-7.

${ }^{21}$ If the Commentary on the Republic (Dörrie-Baltes III 80.6 = Theon, Expositio 146.3-4 Hiller) was not primarily mathematical, then the Expositio might almost be regarded as the required sort of work owing to the liberal use it makes of various passages of the Republic.

22 The identity of the two is unproven; the fragment (Dörrie-Baltes III 80.7) is derived from a work relating to mechanics (Ps-Hero) and purportedly giving a definition of geometry, while the parallel passage in the anonymous Commentary on the Theaetetus (col. XV) is treating simple as opposed to systematic knowledge in particular: a distinction relevant to mathematics, which is prominent in the context. Taurus may have been commenting on the epistemology of Republic VI-VII, as Mansfeld suggested $(1983,61)$.

23 By 'regular commentary' I am thinking of a lemmatic commentary dealing primarily with philosophic issues; we cannot be certain what a primarily linguistic commentary on the Republic (such as Schironi 2005, especially 431, attributes to Aristarchus) might have looked like.
}

PLATO, The electronic Journal of the International Plato Society, 12, 2012.

http://gramata.univ-paris1.fr/Plato/article118.html,

(c) All rights of reproduction of any form reserved. 
The works concerned are attributed to Potamo of Alexandria, from the Augustan age, and Onosander (first century A.D.?). A third plural title that fails to include the term bypomnêma(ta) is a work in three books ascribed to Manaichmus (of unknown date). In all cases the title comes from the Suda under the entries for the authors concerned, who are in every case called philosophers, and in the case of Onosander and Manaichmus 'Platonic philosophers'. ${ }^{24}$ Thus we cannot be entirely sure whether we are dealing with a title bestowed on the commentary by its author, or one that had come to be used many centuries later, for the transmitted title of Proclus' Commentary on Plato's Republic actually uses the plural term, though Proclus' own practice in the text is to refer to the Republic by its normal singular title. However, there seems to be something of a pattern in the Suda's references to scholarship on the Republic from centuries earlier, and on balance I favour accepting that titles referring to Plato's Politeiai did exist in this period, which is not far removed in date from that of the Antiatticista.

It has been suggested that the plural title may be linked somehow with Thrasyllus, ${ }^{25}$ since Diogenes Laertius (3.57) reports that this latter counted up to 56 dialogues of Plato by dividing the Republic into ten and the Laws into twelve. Even so, the term 'dialogue' must surely be wrong here, as the number would include the collection of thirteen Epistles (counted as one). Thrasyllus was thus presumably counting papyrus scrolls. The count is only undertaken in the context of the tetralogies, associated with Thrasyllus both by Diogenes (3.56) and by Albinus (Prologue 4), and the tetralogies themselves count the Republic and Laws only once. The title of the Republic remains singular at D.L. 3.56, 3.60, and 3.62 (twice). Finally, the idea that these works tackled the separate books of the Republic might be taken to imply that all or most books were treated exegetically, but it is scarcely credible that Manaichmus' three-book work about the Republic could be treating so much material. Indeed the failure of all three authors to attract the attention of the Neoplatonists suggests that their contribution did not seriously overlap with the interests of later Platonism. From what little the Suda tells us about Onosander we would expect a practical work, with a possible emphasis on the military arrangements. And it is difficult (but not impossible) to imagine a professed Eclectic like Potamo embarking upon a complete set of lectures on a very long work of Plato. Could it not be, then, that these exegetes are using the plural politeiai for the same reason as Aristotle and the Antiatticista, because it is a type of Platonic subject matter to which they are referring rather than a single dialogue? It is possible that all had written works that compared the positions of Republic and Laws on certain matters of constitutional arrangement.

\footnotetext{
${ }^{24}$ It should be assumed that Potamo is the Alexandrian 'Eclectic' discussed by Diogenes Laertius (1.21), whose testimonies are discussed fully in Hatzimichali (2012).

25 See Hatzimichali (2012) 73; Baltes (1993) 202. Neither lacks for alternative explanations.
} 
It is clear, I believe, that prior to chapter 34 of Alcinous' Didascalicus (from the second century $\mathrm{AD}$ perhaps) there had been some discussion of the different types of constitution supposedly found in Plato, with the non-foundational ( $\dot{\alpha} \nu v \pi \dot{\partial} \theta \varepsilon \tau \circ \varsigma)$ constitution being the subject matter of Republic and two kinds of constitution that work upon pre-existing foundations ( $\dot{\xi} \xi \dot{\xi} \tilde{v} 0 \theta \dot{\varepsilon} \sigma \varepsilon \omega \varsigma)$ being the subject of Laws and Epistles. Interestingly, this division and its terminology had its roots in the fourth book of Aristotle's Politics (1288b21-39), before mention of Plato's 'constitutions' is made at 1293b1. It is certain that Alcinous is crediting Plato with outlining a plurality of politeiai $(188.8-9,188.36)$, and unlikely that this was an innovation of his own.

Frankly it is difficult to make any decision on the basis of such slender evidence, but the principal conclusion that I would draw is that one should avoid referring to these philosophers as authors of 'commentaries on the Republic'. Even if they were, that is not what we are told about them.

\section{iv. Platonists after Proclus and the interpretation of the Republic}

This is no longer what the plural means when we reach the Alexandrian Platonists who followed Ammonius, son of Hermeias. Ammonius himself, like Proclus if unlike Proclus' biographer Marinus (VProc. 14), does not seem to use the plural to indicate a title, ${ }^{26}$ but Olympiodorus wavers. The title appears only in the singular in the commentaries on the Alcibiades and the Phaedo, ${ }^{27}$ but once in the singular and once in the plural in that on Aristotle's Meterologica. ${ }^{28}$ In the Gorgias-commentary it is found nine times in the plural and between three and five times in the singular according to one's stance on details. ${ }^{29}$ At 241.4-242.4 we have a microcosm of this situation, with three plurals and two singulars, including one of each at 241.12! Some inconsistency is perhaps not unexpected in a commentary 'from the voice'. In the related, but anonymous, Prolegomena to Plato's Philosophy there are four singulars and perhaps five plurals. ${ }^{30}$ In other authors of this school, we find Pseudo-Elias having plurals at Isag. 14.22.26 and 22.44.17, followed by singulars at 22.44.18 and 23, while Philoponus has two plurals in the commentary on Nicomachus, of which 32.1 is a genuine reference

\footnotetext{
${ }^{26}$ Note that there is a plural at II.227.3 which translators concur in seeing as a reference to Laws VI 757a; hence this is further confirmation of the plural to be used inclusively of Laws.

${ }^{27}$ I count nine cases in the former, and only one in the latter.

28 Singular at 144.33, plural at 100.19 .

29 At 41.14 it is not clear that this is a title, and at 100.19 it is used to refer to Laws 709 e. This may be either a simple mistake resulting from a slip in oral delivery (for the index to Westerink's 1970 text shows that Olympiodorus was quite familiar with Republic, as also with book IV of Laws) or a case where the term is used, albeit confusingly, to mean simply 'constitution'.

${ }^{30}$ One must allow that 17.29 may be a joint reference to Republic and Laws.
} 
to the Republic, and 15.53 actually refers to the Laws. Asclepius also has the plural at in Nicomachum 11.68. It may be relevant that the important early manuscript Parisinus A has the plural title, for Westerink feels that this owes its origin to this early manuscript's having been influenced by an Alexandrian exemplar. ${ }^{31}$ It does not of course indicate the true title of the work.

The sudden explosion of unambiguous references to the Republic in late antiquity demands an explanation. The special prominence of Olympiodorus here, and above all of his Commentary on Plato's Gorgias, offers a clue. The Republic is seldom far away from Olympiodorus' mind in this commentary, as has been previously observed. ${ }^{32}$ 'Constitutional happiness' had become the key link between Republic and Gorgias, and the emphasis was firmly on the inner constitution within the soul of the individual, mirroring that of the state (in Gorg. proem, 4-5). Whereas Proclus had tended to stress that constitution of soul and state were one and the same (in Remp. I.11.12-13), Olympiodorus prefers to see an analogous relationship between the two. So whereas for Proclus it was probably more accurate to see the constitution that is the subject of the Republic as one constitution with two manifestations, in Olympiodorus the Republic is indeed a work that promotes two constitutions. ${ }^{33}$

Hence we have found a theoretical basis for believing that one would correctly refer to the Republic by the plural title Politeiai. Of course books VIII-IX had spoken about a plurality of inferior constitutions, both civic and individual, but they were not Plato's constitutions. Up until this period the conventional title had not yet seemed a problem for the philosophers. ${ }^{34}$

\section{Conclusion}

For these reasons it would seem to be illegitimate to expect that the early imperial bypomnêmata that used the plural Politeiai should be using it for the same reason as the Alexandrian Neoplatonists (particularly Olympiodorus) did centuries later. They simply did not have the same theoretical basis for doing so. To the best of

\footnotetext{
31 Westerink (1981), 115.

32 Tarrant (1997).

33 There may be another factor that applies here. Proclus, presumably following Iamblichus, had rejected the inclusion of Republic and Laws in his restricted curriculum precisely on the grounds that each is a plurality of logoi, as reported in the Prolegomena (26.3). In this context the Prolegomena employs the plural title.

${ }^{34}$ It is noticeable that in the passage of Olympiodorus' Commentary on Aristotle's Meteorologica the one passage that uses the plural title (100.19-24) is actually discussing the way that the ideal constitution relates to the discussion of justice that had been begun. However, it would be very difficult to establish any clear pattern of reference in the Prolegomena or the in Gorg.
}

PLATO, The electronic Journal of the International Plato Society, 12, 2012.

http://gramata.univ-paris1.fr/Plato/article118.html,

(c) All rights of reproduction of any form reserved. 
our knowledge Marinus is the first Neoplatonist known to employ the plural title, in his Life of Proclus of AD485-6. Nor can we be sure that he did so for the same reason as Olympiodorus and some of his Alexandrian colleagues. Before the fifth century AD the default explanation of any title-like reference to Plato's politeiai should be that it is a reference to the political systems as found in both the Republic and the Laws. Such a hypothesis makes best sense of the reference in Aristotle's Politics, helps to explain the active voice and the omission of a booknumber in the Antiatticista, and does not run counter to what we know of exegetical works involving the Republic.

Harold TARRANT

University of Newcastle

PLATO, The electronic Journal of the International Plato Society, 12, 2012.

(c) All rights of reproduction of any form reserved. 


\section{BIBLIOGRAPHY}

Baiter, J.G., Orelli, J.C., and Winckelmann, A.W. 1839. Platonis opera quae feruntur omnia, Turin: Meyer \& Zeller, 970-1010 (Timaeus Sophista, Lexicon Platonicum).

Bekker, Immanuel (ed.). 1814. Anecdota Graeca, Berlin: Nauck. [Text of Antiatticist $=\mathrm{I} .75-116]$

Bonelli, Maddalena. 2008. Timée le Sophiste: Lexique platonicien, Leiden: Brill.

Dörrie H. and Baltes M. 1993. Der Platonismus in der Antike III, Stuttgart-Bad Cannstatt: frommann-holzboog, 203-4

Dyck, Andrew R. 1985. 'Notes on Platonic Lexicography in Antiquity', HSCP 89, 75-88.

Hatzimichali, Myrto. 2012. Potamo of Alexandria and the Emergence of Eclecticism in late Hellenistic Philosophy, Cambridge: CUP, 72-73.

Lee, John A.L. 2013. 'The Atticist Grammarians', in Stanley E. Porter and Andrew W. Pitts (eds), The Language of the New Testament: Context, History and Development, Leiden: Brill.

Mansfeld, Jaap. 1983. 'Intuitionism and Formalism: Zeno's Definition of Geometry in a fragment of L. Calvenus Taurus', Phronesis 28, 59-74.

Ritschl, F. (ed). 1832. Thomae Magistri sive Theoduli monachi ecloga vocum atticarum, Halis Saxonum.

Schironi, Francesca. 2005. 'Plato at Alexandria: Aristarchus and the "Philological Tradition” of a Philosopher', CQ 55, 423-34.

Slings, S.R. 2003. Platonis Rempublicam, Oxford: Oxford Classical Texts.

Tarrant, Harold. 1997. 'Politike Eudaimonia: Olympiodorus on Plato's Republic', in K. Boudouris (ed.), Plato's Political Theory and Contemporary Political Thought, vol. II. Athens. 200-207 (reprinted in H. Tarrant, From the Old Academy to Later Neo-Platonism, Farnham: Ashgate, 2011).

Tarrant, Harold. 2012. 'The Origins and Shape of Plato's Six-Book Republic', Antichthon, 46, 52-78.

Westerink L.G. (ed.). 1970. Olympiodorus, In Platonis Gorgiam Commentaria, Berlin: Teubner.

Westerink, L.G. 1981. 'The Title of Plato's Republic', Illinois Classical Studies 6, 112-115.

PLATO, The electronic Journal of the International Plato Society, 12, 2012.

http://gramata.univ-paris1.fr/Plato/article118.html,

(c) All rights of reproduction of any form reserved. 